\title{
Business Feasibility Study of Hotel X at Pasuruan Regency, East Java
}

\author{
Dino Leonandri \\ Sekolah Tinggi Pariwisata Trisakti \\ *dinoleonandri@stptrisakti.ac.id
}

\begin{abstract}
This article describes a feasibility study for a hotel development in Pasuruan, East Java. The potential city of Pasuruan has begun to develop as a trade, government and service area and the construction of this hotel is expected to increase local revenue (PAD) as well as both contributing to the economy of the local community and providing benefits to the investors. The research uses qualitative method and data gathered by both interview and data collecting. The variable of this research is business feasibility and the analysis unit is Hotel X. From the research analysis, it was found that development hotel in Pasuruan is feasible and can be continued.
\end{abstract}

Keywords: aspects of feasibility, business feasibility, hotel industry 


\section{A. Introduction}

In Indonesia, tourism has been a strategic sector in the national economic system which gives a big contribution to the national income. As a national strategic sector, tourism has a multiplying effect inflicted by the tourism activities, whether a direct effect such as absorption of labor in the tourism sector or an indirect effects such as the development of supporting economic activities like hotels, restaurants, money changer services, etc. The industries which are closely related to tourism are hospitality industry and other accommodation.

Hospitality industry is an inseparable part of tourism. Without tourism activities, hospitality industry will be paralyzed. Vice versa, tourism will not work without accommodation facilities.

As one of the sub-systems of tourism sector, hospitality industry has a strategic role. This is because hotels provide the facilities as temporary residence for those who are traveling. As time passes, the kind of accommodation does not only provide temporary residences but it also fulfills their needs, like recreation, sport, eat and drink, and so on. This improvement effects the kinds and numbers of facilities provided by every hospitality business. As a commercially managed accommodation, hotels nowadays have been an industry that needs huge human and fund resources with high risks of benefits and disadvantages. Therefore, hotels nowadays cannot be managed traditionally; rather it has to be professionally managed.

\section{B. Literature Review}

According to Ibrahim and Gumelar (2011), business feasibility study is an activity to assess to what extent the advantages of a project activity.

Whereas, according to Kadariah, Kahlien, and Clive (1999), a project is the entire activities which use the resources to get benefits or an activity in which money is paid in hope to get return in the future which can be planned, funded, and implemented as a unit. Nicholas and Chinedum (2017) believe that a thorough feasibility analysis provides a lot of information necessary for the business plan. It implies that feasibility studies may offer the chance to - get it rightll before committing time, money and business resources to an idea that may not work in the way you originally planned, causing you to invest even more to correct flaws, remove limitation, and then simply try again.

The purposes of business analysis are as follow (Gray dan Larson, 2007);

1. To find out the level of benefit that can be achieved in a project.

2. To avoid improvidence of resources by avoiding disadvantageous activities.

3. To assess the existing investment opportunity in order to select the most advantageous alternatives of activities.

4. To determine the investment priority. 
Rangkuti in Syarif (2011) explained that the ability to analyze marketing is very important to a company's success. If a company succeeds in selling more products with similar quality with higher price or in developing a new product which is more successful, the company has been succeeded in using the marketing analysis ability. through:

Kotler in Syarif (2011) explained that the market potential can be analyzed

a. An approach of demand emphasizing on the unfulfilled or fulfilled yet unsatisfying human needs.

b. An approach of offer starting from the ability to create a product, and give service, or combine both.

c. To limit the market range, measure rationally your business and determine your target.

The business feasibility study is an activity of deeply studying a business to be run in order to determine is the business is feasible to run (Kasmir dan Jakfar, 2012). Hussain Umar (2001) explained that a feasibility study of a project is a research of feasible or not a business project to be run. The business project is usually an investment project. Feasibility means a measurement if the project has been operated and resulted in expected advantages or not.

Pasuruan is a city in East Java Province. This city lies 60 kilometers southeast of Surabaya, the Capital of East Java and 355 kilometers northwest of Denpasar, Bali. The entire territory of the city is surrounded by Pasuruan Regency. Pasuruan City lies in the main lane of North Beach (Pantura) which connects Java Island with Bali Island, which makes it a city with high prospect of economy in the East region of Indonesia.

In order to anticipate the increasing numbers of tourists and businessmen coming to Pasuruan City, the supporting facilities are needed, including those from hospitality sector. Seeing this opportunity, a company plans to build 'Hotel X' which is funded by Bank $\mathrm{A}$, this is aimed at giving more convenience to tourists and customers of the hotel.

\section{Research Methodology}

This research uses quantitative method, and the kinds of data used for this research consisted of primary and secondary data, both qualitative and quantitative data. In this research, we gather data about trend and market of tourism and hotel in Pasuruan for the last few years. Data is collected by using documentation and interview method. Documentation method means the data collection by searching through the data history (Ibid, in Rohmatul, 2009). The documents used for this study included report, books and notes, meanwhile the interview done to some individuals in tourism and hotel industry. These methods are used to collect data of the feasibility of Hotel X in Pasuruan City. 


\section{Result and Discussion}

The description of the study on Hotel $\mathrm{X}$ is planned to take place at $\mathrm{Jl}$. Soekarno Hatta in Pasuruan City as large as $8.192 \mathrm{~m} 2$ area. The construction is aimed at anticipating the tourist increasing coming to Pasuruan City.

Accommodation in Pasuruan City generally consisted of hotels classified as starred hotel as many as 2 units, one unit of Three Starred hotel and one unit of two starred hotel. If Hotel $\mathrm{X}$ is built, it will add the number of three starred hotel to two units.

\section{Limitation of Study}

The data that will be used in this study is data related to the aspects being examined, including the aspects of financial, market, technical which concern about selling and the cost spent during the project, the tourists coming to Pasuruan Citi, and the data of hotels in Pasuruan.

The aspects of business feasibility analysis include market and marketing aspects, technical aspect, and financial aspects. The variables discussed within each aspect is adjusted to the business condition which is being run. The following are explanations of each aspect:

\section{Market and Marketing Aspects}

The current market potential, the level of room occupancy (LRO) of starred hotels in East Java in November 2015 were $61.45 \%$, it rose 0.87 points than that of October 2015 which was $60.58 \%$.according to Star Classification, the LRO of 4 starred hotel in November 2015 was $76.14 \%$. It was the highest level compared to the LRO of other starred hotels. Next, the LRO of 5 starred hotels was $56.94 \%$, followed by 3 starred hotels as many as 56.17\%, 2 starred hotels $54.28 \%$, and 1 starred hotels $42.03 \%$.

\section{Marketing Strategy}

Marketing strategy means the marketing strategy which is applied after the business have been run and is possible to make addition or changes. Goi (2005) define marketing strategy as the set of the marketing tools that firms use to pursue their marketing objectives in the target market; the view which was earlier expressed by (Gronroos, 1999, and Osuagwu, 2006). Therefore, the function of marketing strategy is to determine the nature, strength, direction, and interaction between the marketing mix- elements and the environmental factors in a particular situation. According to Owomoyela et al (2013) the strategy included:

a. hotel facilities with 140 rooms and the biggest ballroom in the city that can catered up to 1.000 standing guest

b. hotel participation on tourism events such as Borobudur Travel Mart, MG Trade Show in Surabaya 


\section{Financial Aspect}

Investment needed for this business consisted of the costs of construction, utilities, procurement of goods, and so on. these costs are counted on the basis of real count. The following are the estimated costs based on the business:

\section{Investment Plan}

The total investment needed for this projects was IDR 70.421.000.000,(the value of land is excluded), it covered the costs for hotel construction, supporting facilities, and other operational costs, in which the development needs about 18 months to build until the hotel operated.

\section{Analysis of Project feasibility.}

The economy in East Java in the third quarter of 2015 grew as many as 5.44\%. The economic growth occurs in all aspects of the business, except in the category of electricity and gas provision which suffered contraction as many as $3.74 \%$. The provision refreshment run into the highest growth as many as $7.85 \%$, followed by Health service and social activities as many as $7.47 \%$; financial and Insurance services rose as many as $6.73 \%$; Information and communication $6.62 \%$, and education service $6.38 \%$.

The LRO on table 2 below showed that the starred hotels in East Java in November 2015 was 61.45. increased 0.87 points from October 2015 (60.58\%). According to Star Classification, The LRO of 4 starred hotels in November 2015 was $76.14 \%$, it wa s the highest level compared to other starred hotels. The LRO of 5 starred hotels was $56.94 \%$, followed by 3 starred hotels $56.17 \%$, two starred hotels $54.28 \%$, and 1 starred hotels $42.03 \%$.

1. East Java's economy in the third quarter of 2015 grew by $5.44 \%$. Growth occurred in all business fields, except the Electricity and Gas Supply Category which contracted by $3.47 \%$. Provision of Accommodation and Food and Drink is a business field that experienced the highest growth of $7.85 \%$, followed by Health Services and Social Activities of 7.34\%; Financial Services and Insurance 6.73\%; Information and Communication 6.62\% and Education Services 6.38\%.

2. Room Occupancy Rate of starred hotels in East Java in November 2015 reached $61.45 \%$, up 0.87 points compared to the TPK in October 2015 which reached $60.58 \%$. According to star classification, the ROR for 4 -star hotels in November 2015 reached 76.14\% and was the highest ROR compared to ROR for other star-rated hotels. Furthermore, the ROR for 5 -star is $56.94 \%$, followed by 3 -star hotels by $56.17 \%$, 2 -star by $54.28 \%$, and 1 -star hotels by $42.03 \%$

3. The results of the net present value (Net Present Value) of the difference in cash for 10 years projection with a discount factor of $13.46 \%$ is positive at Rp. 53.177.765.889 -

4. To return the investment value of Rp. 70.421.000.000, - takes \pm 6 years. 


\section{Analysis of Net Present Value (NPV)}

The result of test of the Net Present Value of the cash devisation in 10 years of the projection with discount factor as many as $13.46 \%$ was positive as many as IDR 53.177.765.889,-

\section{Pay Back Period}

To return the investment values as many as Rp. 70.421.000.000,- needs about six years .

\section{Profitability index}

The level of profitability index or usually called the Benefit Cost Ratio for this investment project with a projected cash flow for 10 years is 1.5496 times, which means the total cash flow balance is greater than the investment value of $154 \%$.

\section{E. Conclusion}

The conclusion of this study of the business feasibility was that from all aspects including aspects of market and marketing, technical, management and organization, law, financial, and the social economy, the construction of the 3 starred hotel named Hotel $\mathrm{X}$ was feasible. This hotel is believed to bring advantages to many parties involved such as investor, government, and the people live in its surrounding.

\section{REFERENCES}

Abdullah, M. Faisal. (2002). Dasar-dasar manajemen keuangan. edisi kedua. Malang: UMM Press

Ahmad Subagyo. (2008). studi kelayakan teori dan aplikasi. Jakarta: PT Elex Media Komputindo Kasmir dan Jakfar. (2012). Studi Kelayakan Bisnis. Edisi Revisi. Jakarta: Kencana Prenada Media Group.

Goi, C. L. (2005). Marketing mix: a review of 4Ps or more".Journal of Internet Banking and Commence, 10. [13]. DOI:10.5539/ijms.v1n1p2

Grönroos, C. (1999). From marketing mix to relationship marketing: towards a paradigm shift in marketing. Management decision, 32(2), 4-20. DOI:10.1108/00251749710169729

Kasmir dan Jakfar. (2012). Studi Kelayakan Bisnis. Edisi Revisi. Jakarta: Kencana Prenada Media Group.

Nicholas, AI \& Chinedum, AH. (2017). The role of feasibility studies on project and organizational performance. International Journal of Research in Social Sciences Vol. 7 Issue 5, May 2017, https://www.ijmra.us/project\%20doc/2017/IJRSS MAY2017/IJMRA11422.pdf, accessed on April 22, 2020 
Nurmalina, Rita. Tintin Sarianti dan Arif Karyadi. (2010). Studi kelayakan bisnis. Bogor: Departemen Agribisnis FEM-IPB.

Osuagwu, Linus. (2006). Market orientations in nigerian companies, intelligence and planning, 24, 6), 67-73. https://www.academia.edu/2155266/Market Orientation In Nigerian Manufacturing Companies?auto=download, accessed on April 22, 2020

Roefeliana, Insani. (2007). Analisis kelayakan finansial produk madu dalam kemasan Sachet, Bogor : Institut Pertanian Bogor.

Umar, Husain. (2001). Studi kelayakan bisnis. Jakarta: Gramedia Pustaka Utama. 